\title{
Investigating Cyber Bullying: Pervasiveness, Causes and Socio-psychological Impact on Adolescent Girls
}

\author{
Swity Sultana Monni (Corresponding author) \\ Student of Department of Public Administration \\ Shahjalal University of Science and Technology \\ Sylhet, Bangladesh \\ E-mail: switysmonni@gmail.com
}

\begin{abstract}
Alma Sultana
Student of Department of Political Studies, Shahjalal University of Science and Technology

Sylhet, Bangladesh
\end{abstract}

Received: October 10, 2016 Accepted: October 28, 2016 Published: November 28, 2016

doi:10.5296/jpag.v6i4.10132 URL: http://dx.doi.org/10.5296/jpag.v6i4.10132

\begin{abstract}
Technology affords abundant benefits to us but the more we are beneficent by the technology, the more the problems consequent to the technology emerged. As the use of internet in Bangladesh is increasing day by day, Cyber bullying is now considered as an emerging threat for the adolescent girls in Bangladesh. The primary objective of our paper is to elicit the causes and socio-psychological impact of cyber bullying toward our girls. Here, we collected data from 50 female respondents purposively from Sylhet City Corporation Area and applied survey method for conducting the research, we also followed case study and observation method in a little extent .Although people of all ages can be the victim of cyber bullying, In this paper our special focus is on the harassment of young girls due to cyber bullying which creates a great effect on their psychological health resulting a boundless depression, on their social status bringing about much defamation and finally may suicidal intension to get rid of this deviant and harmful behavior. We are hopeful that our research will be helpful for the further study on this issues and draw attention to our government to take effective steps to diminish this serious problem.
\end{abstract}

Keywords: Cyber bullying, Information and Communication Technology, Adolescent Girl 


\section{Introduction}

Information and communication technology is now a vivacious part of all ranges of our social and personal life. Internet has become the backbone of all sorts of communication systems and it is also one of the most vital bases of information in the present digitalized world. Branded cyber bullying, youths are poorly utilizing computer and technology like as cellular phone, computer and internet to bully and oppress others (Schenk \& Fremouw, 2012).

In this digital era, the use of mobile phone and internet is increasing so various social networking sites like Facebook, Twitter, Instagram, WhatsApp etc. are gaining popularity day by day for social and personal communication. In these sites online spaces are so open and there is nothing like private. So anyone of any ages can be a victim of cyber bullying but girls are the worst victim of this deviant social crime and now a days, It is frequent in Bangladesh. This type of online bullying is unlike traditional bullying following the girls from classroom or campus to the secrecy of their bedroom, from the time they wake up to the moment before sleep, anytime they may face it with e-mail, texting, recording by social media or communication media (Aune, 2009). Girls are targeted mostly by licking their personal information, personal images or videos or simply by threatening them if there is any hostile relationship or rejection of love or sometimes there is no reason but just for his or her own intention who wants to bully other. Sometimes personal incidents of girls are photographed and video recorded by cellular phone cameras or videos, than these pictures or videos posted on the internet(Campbell,2005).This type of behavior causes a serious hazard to the socio- psychological condition of victim sometimes that leads to commit suicide towards the victims. Cyber bullying is a very serious problem and action required to be taken to diminish this kind of harassment (Reilly, 2010).As cyber bullying is a serious problem to our society, it is high time to give attention to this problem and take necessary steps to diminish this situation.

\subsection{Statement of the Problem}

Cyber bullying is an old issue within a new semblance for Bangladesh. Cyber bullying is varied with old-style bullying because technology offers anonymity towards the people (Aune, 2009). In a few days ago girls were victimized face to face in street, or in school or anywhere but today this forms of bullying is replaced by the use of computer or cell phone. In most cases the victim has to bear the burden of such kind of tremendous experience alone. They don't share this with their family or friends from the fear that if the claiming finger sight through on her or if her family become degraded on society for her and so on. . If they share sometimes with their family, their family has to suffer from defamation and debase by our traditional structure of society. for this reason the victim passes a serious psychological trauma that may cause a dangerous loss on her life sometimes, that cause the girls to be heartbroken, to diminish her cherished desire, to exhaust her own life by herself; by committing suicide As there is a few research on this issue, many of the adolescent's as well as the guardian's don't know details about the problem even don't know what to do if affected by cyber bullying and do not seek shelter of law as lack knowledge about the problem. This emergent problem has as yet not gained the concentration it deserves and 
becomes almost absent from the investigation works (Campbell, 2005). In this research, by exploring its cause and effects we try to focus this issue seriously towards the people and the policy maker to create awareness about the problem and to take proper steps for solving the problem.

\subsection{Background of the Study}

The present government of Bangladesh has special focus on Information and Communication technology. With the proclamation of "Vision 2021", government vowed to make a "Digital Bangladesh" by providing internet access to all people. Now a day's, maximum people have smart phones, computer and available internet facilities which plays a great role in our socio technological advancement but this have dark sides too. For the accessibility of computer and technology, in recent times a new method of bullying has appeared that creates the worst use of wide range of technology by using technology like cellular phones, computer through email, texting and various social networking websites(Campbell,2005). Various cybercrimes like cyber bullying, cyber harassment, cyber stalking has raised. Cyber bullying is generally a greater chance to happen between dating spouses, who have a romantic relationship or existing or former friends between adolescents (Prothom Alo, August, 2016).

Like any other cybercrime, cyber bullying has a tremendous impact on our socio-cultural and psychological condition. But for the effective implementation of cyber law, the effects of this problem are rising day by day. Again most of our young children and guardians are not aware of this problem, for this reason they cannot face this problem properly which risen the level of its impact on our society. In our study we tried to prove this issue as a social problem by exploring the reasons behind its occurrence and by measuring the level of the sufferings of the victim, of his or her family as well as her society.

\subsection{Rationale of the Study}

Cyber bullying is a relatively recent phenomenon that can have significant consequences for young people's wellbeing due to the precise technological affordances of social media. The use of mobile phones and the internet has grown at a tremendous rate in this century. With the advent of mobile, wireless Internet access, communications have become more universal. As a result, Cyber bullying can happen any time and any place and for many girls. According to a report of UNB, In Bangladesh, about 50 percent student became experienced with cyber bullying (Prothom Alo, 2016). Home is no longer a refuge from negative peer pressure such as bullying. The victim of cyber bullying is under the high risk of the emotional, psychological and social difficulties which may keep him or her separate from the family, friends and society and intended to commit serious harm by herself (Gleeson, 2014). In all, we demonstrate how this important social problem which arises due to computer technology can also leverage computer technology in order to take steps to better cope with the unwanted effects that have arisen. Cyber bullying is an embryonic threat for Bangladesh, but most of the girls are not aware of this problem and do not know what to do if faced with cyber bullying. As there are a few research about this problem, we tried to focus this serious issue, its causes and tremendous impact on our society so that this problem can be concerned seriously and preventive measures will be taken to weaken the problem. 


\subsection{Research Objectives}

i. To scrutinize the prevalence of cyber bullying on our girls.

ii. To explore the causes of cyber bullying.

iii. To measure the socio-psychological impact of cyber bullying on girls in our society.

\subsection{Research Questions}

i. What is cyber bullying?

ii. Why girls are the worst victim of cyber bullying?

iii. How incidence of cyber bullying towards our girls?

iv. Which electronic media are connected to Cyber bullying?

v. How frequent the cyber bullying is towards an adolescent?

vi. What are the main causes of Cyber bullying?

vii. What is the major impact of cyber bullying on the socio-psychological sphere of the victim?

viii. Does Cyber bullying accelerate suicidal behavior?

ix. Is the victim faced social dilemma due to cyber bullying?

x. What are the responses of cyber bullying to the family and society of the victims?

\section{Review of the Relevant Literature}

Mohammad Mostufa Kamal, Iqbal Ahmed Chowdhury, Nadia Hague, Mydul Islam Chowdhury \& Mohammad Nazrul Islam(2012), found from their research that like many advanced countries, Bangladesh is not so developed in internet facilities, so the problems or crimes caused by the development of internet and communication technology is now in an evolving stage. They also stated that the victim of the cybercrimes are not conscious about the problem and they should become more concerned that how to prevent and tackle the problems.

The study conducted by Hinduja \& Patchin (2008) focused on that how prevalence of cyber bullying towards female and why adolescent girls are the worst sufferer due to cyber bullying. They explored that since the nature of cyber bullying is message based and it is easy way to harass the girls by licking their personal information or images or chatting conversation, if anyone wants to debase a female, it is very easy for him or her by adapting the ways of cyber bullying.

According to Nicole M. Aune (2009) said that the person who affected by cyber bullying may suffer from depression, anxiety, trauma and low self-confidence. He also argued that this may the result of extreme consequences like as suicide and violence.

Helen Gleeson (March, 2014) conducted his study on the existing condition of cyber bulling 
and the serious mental effect and suicidal behavior of the victims caused by the cyber bullying closely connected to social media. He also focused on the environmental influence of the cyber bullying such as: influence of parents and family, interpersonal relationship, school, college and media.

Nancy Sharoff in her study named "Cyber bullying - The New Age of Harassment", explored the paradox realities of the victims by analyzing the long term effects of Cyber bullying on the family and society of the victims. Her study was basically school based measuring the causes of cyber bullying and finally offer tips for the school to remove this problem.

Using Computer Technology to Address the Problem of Cyber bullying, R. Cohen, D. Y. Lam, N. Agarwal, M. Cormier, J. Jagdev, T. Jin, M. Kukreti, J. Liu, K. Rahim,R. Rawat, W. Sun, D. Wang, M. Wexler, Branding "Cyber Bullying" as a communal problem and measuring the far reaching impact of it, they proposed a multifaceted solution to mitigate the problem. They also stated that cyber bullying which is caused for computer and technology can be diminished also by computer and technology.

\section{Methodology of the Study}

Methodology is the way to systematically solve the research problem (Aminuzzaman, 2011).

\subsection{Approaches of the Study}

We conducted our investigation on Sylhet City Corporation. Here, a mixed combination of qualitative and quantitative method is used as an approach for conducting the research. Qualitative method is used to observe the thoughts, attitudes and opinion of the respondents and quantitative method is used to categorize the respondents on the basis of their age, sex, educational qualification etc.

\subsection{Research Methods}

This study is an exploratory descriptive research design. Here we used social survey and in a little extent, case study method to elicit the in-depth information about the study.

\subsection{Sources of Data Collection}

The study is based on primary as well as secondary sources of data.

\subsubsection{Primary Sources}

The primary data is collected from 50 female respondents through face to face interviews whose age lies between 10-20 years old.

\subsubsection{Secondary Sources}

Secondary data sources include different books, journals, reports, research works, and daily newspapers, e-books and relevant websites.

\subsection{Sample \& Sampling}

Here we use purposive sampling for collection of data and total sample size is 50 . 


\section{Macrothink

\subsection{Data Collection Technique}

Data is collected through a simple interview schedule. The data is collected by face to face interviews of the respondents randomly using a semi- structured Questionnaire. Using various software's for example; Microsoft excel, data are computerized, analyzed and interpreted.

\subsection{Limitations of the Study}

We tried our best level to explore and to find out the questions arisen from conduction our research with our specific set of objectives. Probably, our study has some limitations like

- We collected data from only a single area, if it would be possible to gather data from much more sphere, it might be more effective.

- Many of the respondents don't want to share their experience even reluctant to tell whether they are the victim or not as cyber bullying is sensitive issue.

- As there is very few research in Bangladesh perspective on cyber bullying, reference for the study may insufficient from Bangladeshi works.

- Most of our respondents were adolescent girls, so they feel ashamed of conversing with an unfamiliar person.

\subsection{Conceptual Framework}

The study "Investigating Cyber Bullying: Pervasiveness, Causes and Socio-psychological Impact on Adolescent Girls" examining the scenario of Cyber bullying in Sylhet City Corporation area, it displays the present image of cyber bullying in Bangladesh. The core objective of this study is to explore the causes and measuring the socio psychological impact of cyber bullying in Bangladesh considering Sylhet city Corporation as our study area. Here, "Cyber bullying" is an independent variable which is caused by many factors like as; moral degradation, unemployment problem, decadence of social values, lack of education and so on. This type of deviant behavior causes a great impact on the socio psycho logical environment of our society which ultimately lead to socio-psychological hazard and in this research, this is our dependent variable. 


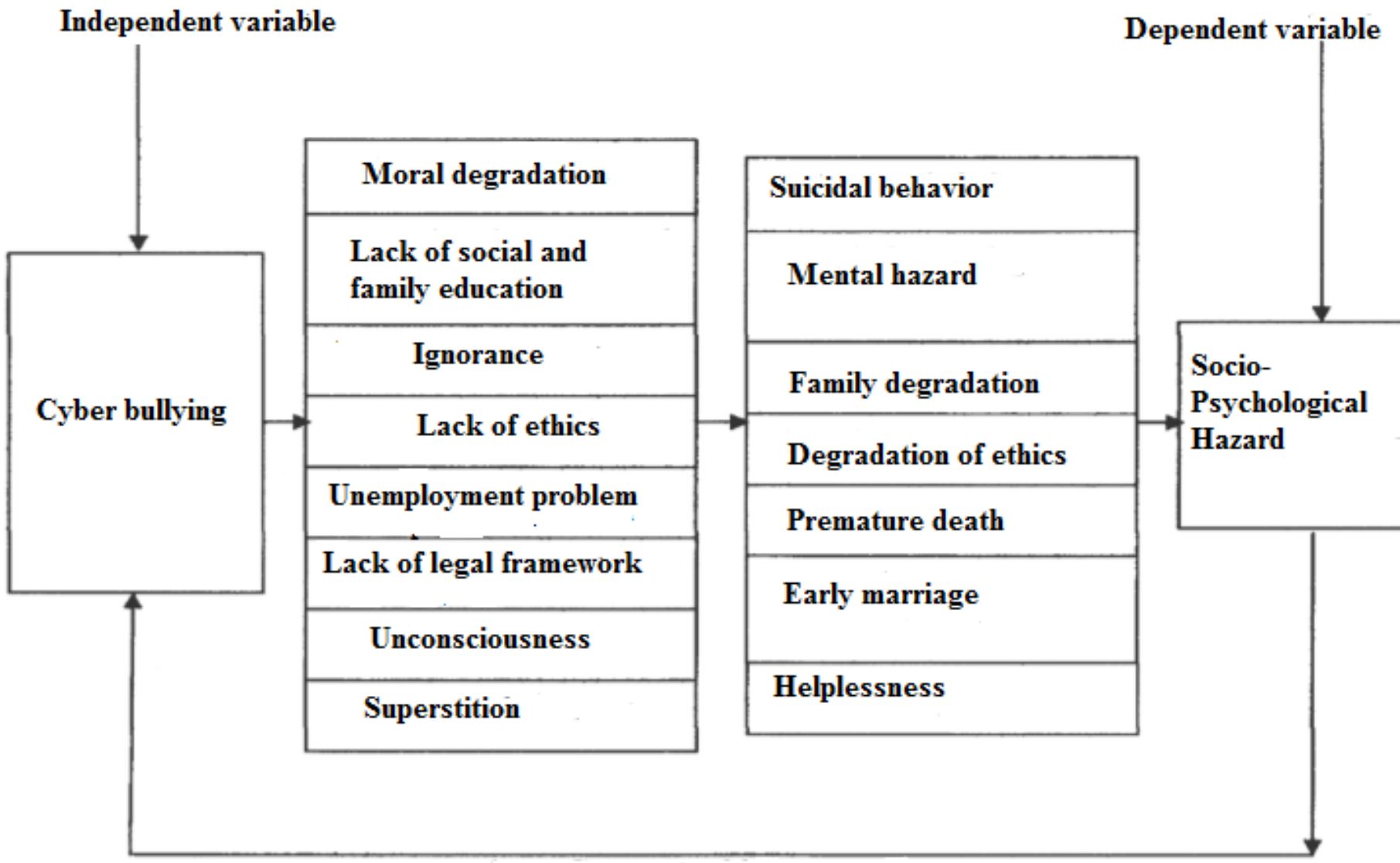

Fig: Conceptual Framework

\subsection{Operational Definition of the Key Concepts}

\section{- Cyber bullying}

Generally, bullying means the act of irritating someone with the intention of harming others. Cyber bullying is that kind of bullying that aims to harass or harm others by using information and communication technology such as cell phones, computer, tablets etc. with the blessings of availability of internet connection to the all sphere of people. It involves oppress someone through internet websites like Facebook, WhatsApp, Twitter, E-mail etc. by posting or sending text messages, photos, videos or by derogatory comments to someone.

\section{- Information \& Communication Technology}

ICT (information and communications technology - or technologies) is the integration of all electronic device or application for information and communication encircling cellular phones, radio, televisions, internet, computer and network hardware and software etc. It also includes a variety of services as like as video conferencing, sound \& video recording, and remote learning etc. Numerous cybercrime as like as cyber bullying are increasing say by day with the advent of information and Communication Technology.

\section{- Adolescent girls}

The word "Adolescence" means "to grow up". It refers to a period of transition of physical and psychological development. This stage begins from puberty and last up to the early 


\section{Macrothink}

twenties. On the other hand, the term "girl" means a female child or young or relatively young women. So the word "Adolescent girl" means a young or teenage girl under the stage of physical and psychological development.

\section{Cyber Bullying}

Cyber bullying, can be branded also as electronic bullying or online brutality is the act of frequent, deviant and oppressive actions by using computer and communication technology targeted to threat, or harm others.

Hinduja and Patchin defined cyber bullying as a "willful and repeated harms inflicted through the use of computers, cell phones and other electronic devices" (Hinduja \& Patchin, 2008).

According to Belsey (2004) "cyber bullying involves the use of information and communication technologies to support deliberate, repeated, and hostile behavior by an individual or group that is intended to harm others" (Belsey, 2004).

It entails the harassment of apprentices by using social media websites, text messages, E-mails and other technology (Reilly, 2010). But now a days, this deviant behavior is not only confined with students but also people of all ages can be the victim of cyber bullying due to the advent of communication and technology. Among them girls are mostly targeted by cyber bullying. The increasing oppression of teenage girls due to cyber bullying highlights the needs of analyze the oppression that occur through the use of online space (Hinduja \& Patchin (2008)).Cyber bulling has not a single sphere. According to Willard (2006), 'there are different forms of cyber bullying. These forms include flaming, harassment, denigration, impersonation, outing, trickery, exclusion, cyber stalking, and cyber threats".

However, the various forms of cyber bullying are discussed below:

- Cyber Harassment: Cyber harassment is very offensive form of cyber bullying that refers to repeated sending of fearful, hurtful or rude text messages from various social networking sites and devices. It includes licking the personal messages or personal information of the victims. 


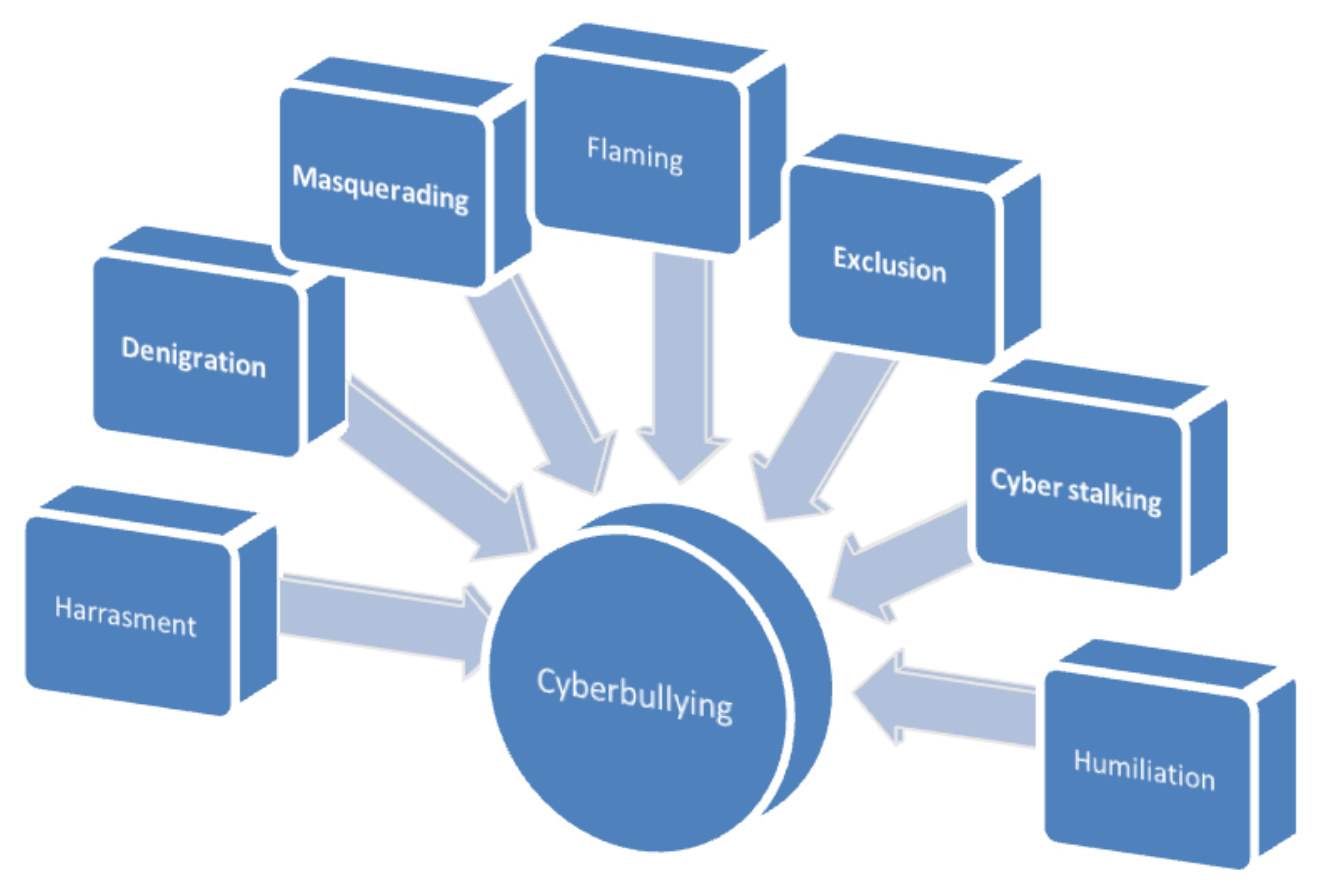

Figure 2: Common forms of cyber bullying

- Denigration: Denigration is such type of bullying which include posting humiliating comments on someone images or about someone which may make him or her upset and stressed. The victims affected by this type of bullying may keep herself far from her family and friends.

- Masquerading: Masquerading is a condition that a bully creates a fake identity to harass someone secretly. By creating a fake personality, the bully can imitate someone by sending offensive and obscene messages. A bully can affects someone by belittle her reputation and status keep himself guise.

- Flaming: Flaming is similar to harassment, but it refers to an online fight exchanged via emails, instant messaging or chat rooms. It is a type of public bullying that often directs harsh languages, or images to a specific person.

- Exclusion: This includes make someone leaving out from a specific group and then spread unfavorable comments about the leaving person

- Outing: If a bully spread someone's personal images, messages, information or videos in public sites from a revengeful intention, this can be called as outing.

- Cyber stalking: Cyber stalking is the most harmful form of cyber bullying can be compared with sexual harassment in cyber world. This includes send someone obscene sexual pictures or videos or messages.

Moreover, our present world is fully depended on the use of digital devices like mobile phone, computer, internet etc. With the advent of technology, use of internet is rising day by day. In this digital era, we cannot think of a single day without various social networking sites like 


\section{Macrothink}

Journal of Public Administration and Governance

ISSN 2161-7104

2016, Vol. 6, No. 4

Facebook, WhatsApp, Twitter, and Instagram and so on. Most cases of cyber bullying in Bangladesh are occurred by using this popular media of social networking sites. From their study on Cyber bullying, Beale and Hall (2007) explore six main ways of cyber bullying, these are: Email, instant messaging, chat rooms or bash boards, small text messaging, Web sites, and voting booths.

\section{Cyber bullying}

- Social Networking sites

- Mobile phone

- Blogs,Forums

- Dangerous websites

- Voice Recordings

- Abusive E-mail

- Personal Website

- Video Email or MMs when send

Figure 3: Various ways of cyber bullying

Facebook are very popular media in our country and at present most of the people of Bangladesh have a Facebook account. Many adolescents girls are victimized by using Facebook for example; by spreading their personal pictures or videos, in most cases this are edited from the real version to make obscene in order to belittle her, or by posting rude status or comments on someone's picture or posts, in a word there are many elements by which one can intentionally degrade anyone. Besides this, the rest other social networking sites, blogs, voice recordings, dangerous websites, abusive e-mail, personal websites all can be considered as a platform by which cyber bullying can be occurred anytime with anyone. The ways the young women are presented in the social media such as Facebook and the system they display and positioned themselves in which the young boys are potentially internalized by adolescent girls who have been exposed to a culture which is highly sexualized. The display of self and body via Facebook and other social media encourages the bully to seek harm of others.

\section{Findings \& Discussion}

\subsection{Age of the Respondents}

In this analysis, we selected 50 adolescent girls purposively as our respondents whose age lies between 10-20 years. Most of the respondents were aged from 13-16. 
Table 1: Age of the respondents

\begin{tabular}{|l|l|l|}
\hline Size & Frequency & Percentage $(\%)$ \\
\hline $10-13$ & 10 & 20 \\
\hline $13-16$ & 20 & 40 \\
\hline $16-18$ & 10 & 20 \\
\hline $18-20$ & 10 & 20 \\
\hline Total & 50 & 100 \\
\hline
\end{tabular}

Field Data collected from Sylhet-Bangladesh, August 5-September 2, 2016.

The data presented in the figure represents that $40 \%$ of the total respondents were aged between 13-16 years old,20\% were belong to the age group 10-13,20\% of total respondents belong to the age group 10-13,20\% from 16-18 aged groups and rest $20 \%$ of the respondents were from the age group of 18-20.

\subsection{Educational Status of the respondents}

Education is the driving force by which adolescent girls can know more about cyber bullying, its causes, and impact on the society and be aware themselves in this regard.

\section{Table 2: Educational Status of the respondents}

\begin{tabular}{|l|l|l|}
\hline Educational qualification & Frequency & Percentage (\%) \\
\hline Illiterate & 1 & 2 \\
\hline Primary & 1 & 2 \\
\hline Secondary & 10 & 20 \\
\hline SSC & 20 & 40 \\
\hline HSC & 10 & 20 \\
\hline Graduation & 8 & 16 \\
\hline Total & 50 & 100 \\
\hline
\end{tabular}

Field Data collected from Sylhet-Bangladesh, August 5-September 2, 2016. 


\section{Macrothink}

In our study only $2 \%$ respondents were illiterate and majority of the respondents are literate, about $2 \%$ of total respondents are in primary education, about $20 \%$ of total respondents are in secondary level, about $40 \%$ of the total respondents belongs to SSC, $20 \%$ belongs to HSC level and $16 \%$ of the total respondents belongs to graduation level.

\subsection{Marital status of the respondents}

This figure shows the marital status of the adolescent girls, the respondents of our study.

\section{Figure 4: Marital status of respondents}

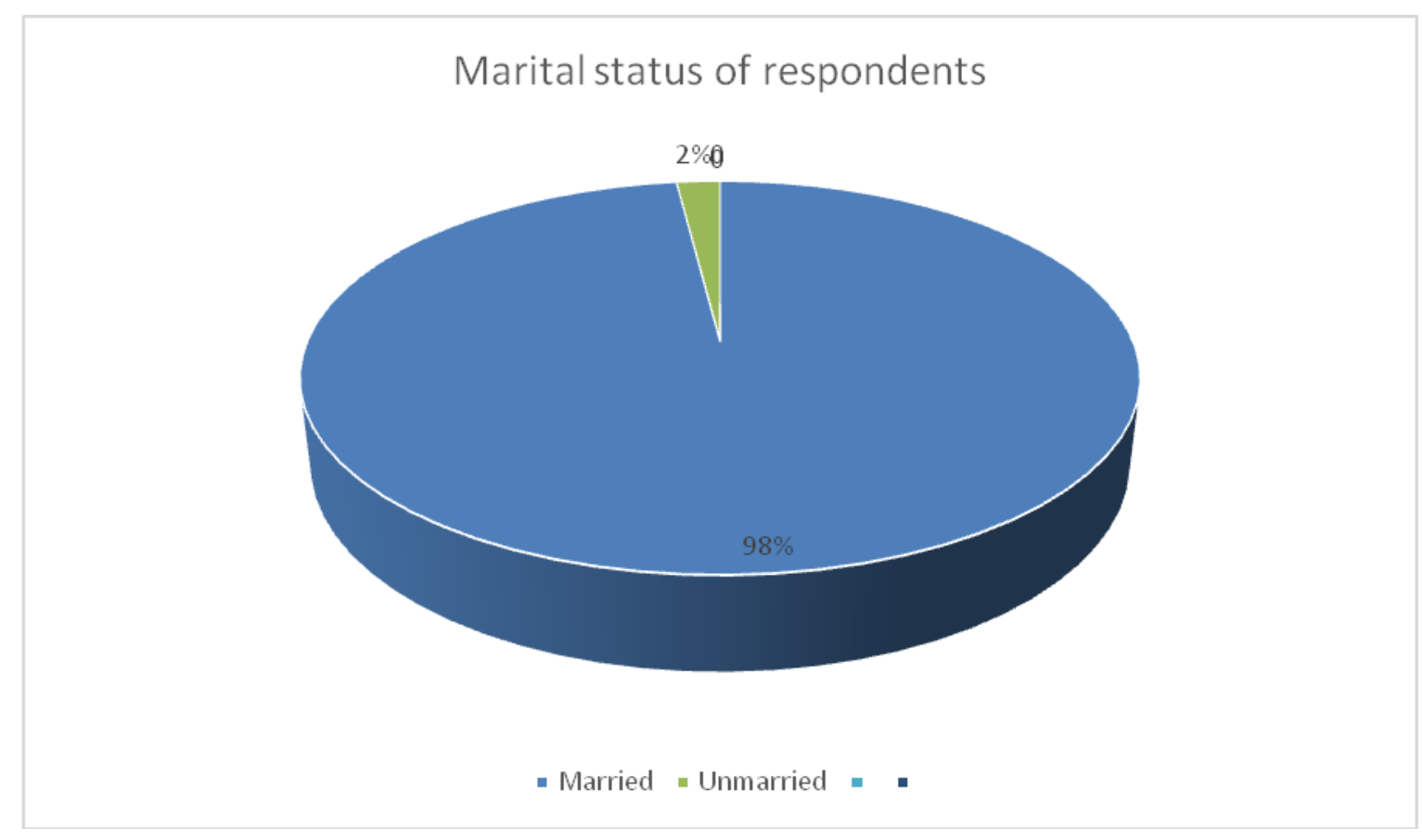

Field Data collected from Sylhet-Bangladesh, August 5-September 2, 2016.

This figure reveals that among all the respondents $98 \%$ girls are unmarried and only $2 \%$ girls are married. Study shows that unmarried girls have frequent experience of cyber bullying than married ones.

\subsection{Prevalence of cyber bullying}

Most of teenagers who have engaged themselves in cyber bullying was connected to traditional bullying before. In a study conducted by reveals that In Ireland, about $23 \%$ of teenage people have experience of outdated bullying while $4 \%$ of these experience cyber bullying(Gleeson, March,2014). 


\section{Macrothink

Table 3: Victimized of cyber bullying or not

\begin{tabular}{|l|l|l|}
\hline Opinion & Number of respondents & Percentage (\%) \\
\hline Yes & 45 & 90 \\
\hline No & 0 & 0 \\
\hline No answer & 5 & 10 \\
\hline Total & 50 & 100 \\
\hline
\end{tabular}

Field Data collected from Sylhet-Bangladesh, August 5-September 2, 2016.

Our question towards the respondent was if there is victimized of cyber bullying or not. 90\% of the total respondent's said "Yes", there is no one who said "No" and $10 \%$ didn't give any answer.

\section{- Level of occurrence of cyber bullying}

This figure measures the level of occurrence of cyber bullying answering the question of is it a rare or frequent experience?

Table 4: Level of occurrence of cyber bullying

\begin{tabular}{|l|l|l|}
\hline Opinion & Number of respondents & Percentage (\%) \\
\hline $\begin{array}{l}\text { Cyber bullying is a frequent } \\
\text { experience }\end{array}$ & 40 & 80 \\
\hline Cyber bullying is rare & 10 & 20 \\
\hline Total & 50 & 100 \\
\hline
\end{tabular}

Field Data collected from Sylhet-Bangladesh, August 5-September 2, 2016.

The data of this table shows that $80 \%$ of the total respondents think that cyber bullying is a frequent experience and about $20 \%$ of the total respondents think that cyber bullying is a rare experience.

\section{- Media by which girls experienced with cyber bullying}

With the advent of technology especially for the different social networking media, cyber bullying is increasing day by day. This study measures the level of occurrence of cyber bullying through different social networking sites. 


\section{Al Macrothink

Figure 5: The level of cyber media connected to bullying

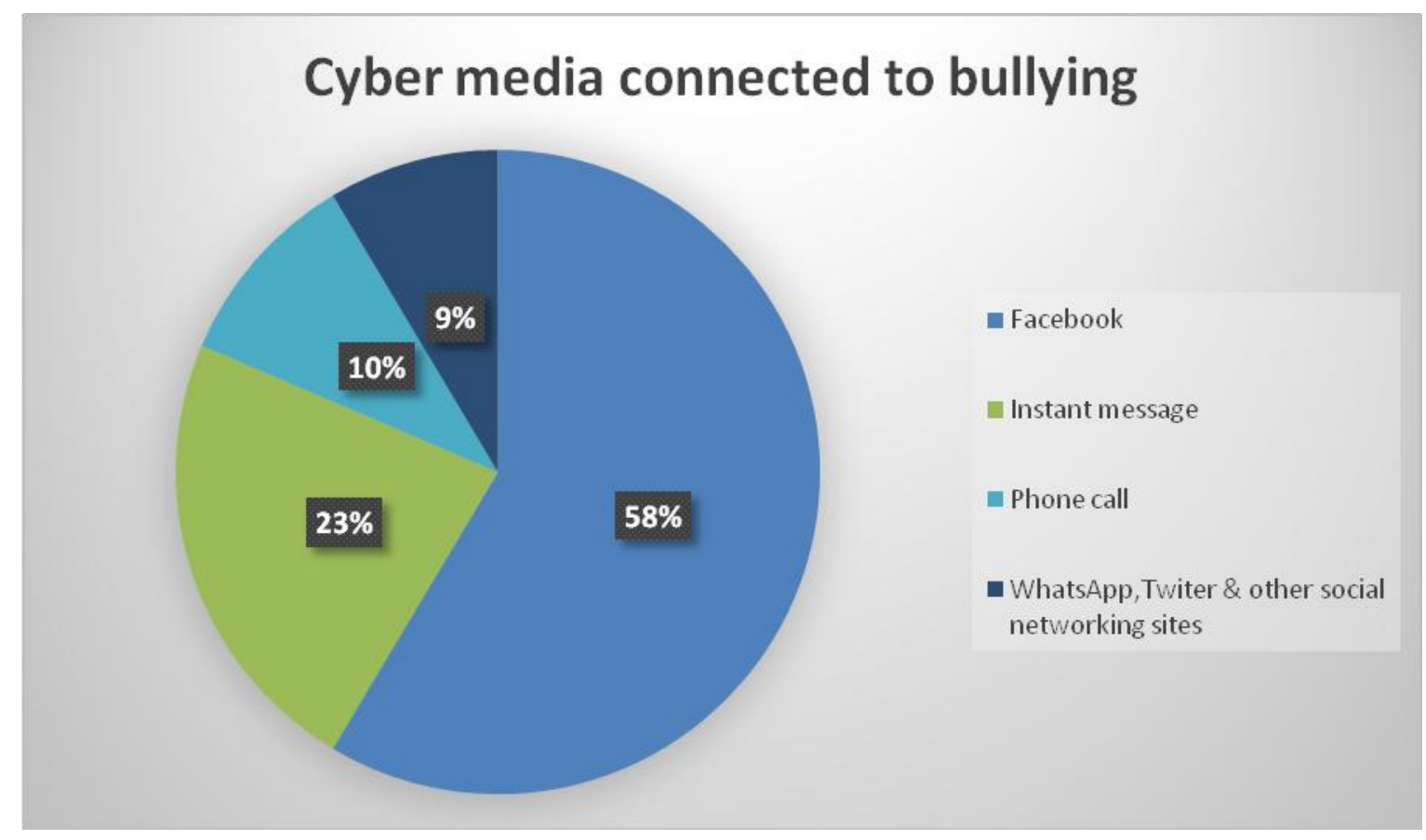

Field Data collected from Sylhet-Bangladesh, August 5-September 2, 2016.

This study shows that Facebook is the most used device of cyber bullying. About 58\% of the total respondents claim Facebook for bullying, 23\% claims instant messaging, 10\% claim phone call and $9 \%$ of the total respondents claim WhatsApp, Twitter and other social networking sites for cyber bullying.

\section{- Responsible guys for cyber bullying}

This figure shows the rate of people who are the most responsible guys categorizing the people as young, middle and old aged. 
Figure 6: Most responsible guys for cyber bullying

\section{People most responsible for cyberbullying}

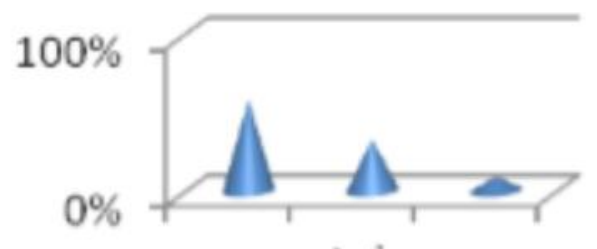

Responsible

individual for cyber

bullying

Field Data collected from Sylhet-Bangladesh, August 5-September 2, 2016.

This figure shows that young people are the most responsible guys for cyber bullying. Then the middle aged who are less liable for cyber bullying than the old aged people

- Frequent rate of cyber bullying

Table 5: Number of time respondents face cyber bullying

\begin{tabular}{|l|l|l|}
\hline Times & Number of respondents & Percentage (\%) \\
\hline One times & 25 & 50 \\
\hline 2 times & 15 & 30 \\
\hline more & 7 & 14 \\
\hline Don't faced & 3 & 6 \\
\hline Total & 50 & 100 \\
\hline
\end{tabular}

Field Data collected from Sylhet-Bangladesh, August 5-September 2, 2016.

In this figure only $50 \%$ of the total respondents experienced with cyber bullying just for one times, $30 \%$ of the total respondents faced with it for two times, $14 \%$ of the total respondents faced it for several times and rest of the respondents said yet they don't face cyber bullying. 


\subsection{Causes of Cyber Bullying}

There are various reason beyond this problematic social phenomena. Hinduja and Patchin, from their research, they explored top three causes of cyber bullying that 22.5 percent of their total respondent's claims revenge, $18.7 \%$ of their total respondents said that it occurs because the victims deserve it and $10.6 \%$ of their total respondent's cyber bullying occurs with the intention of fun (Hinduja and Patchin (2009). Competition for status and prestige between the friends or peers is one common reason of cyber bullying (The Prothom Alo, August 23, 2016).

\section{Table 6: Causes of cyber bullying}

\begin{tabular}{|c|c|c|}
\hline Cause of cyber bullying & Number of respondents & Percentage $(\%)$ \\
\hline Relationship problem & 13 & 26 \\
\hline $\begin{array}{l}\text { Self-display of girls in social } \\
\text { media }\end{array}$ & 7 & 14 \\
\hline Moral degradation & 9 & 18 \\
\hline Unemployment problem & 5 & 10 \\
\hline Lack of education & 4 & 8 \\
\hline Unawareness of girls & 2 & 4 \\
\hline Intention of teenage & 3 & 6 \\
\hline $\begin{array}{l}\text { Unawareness } \\
\text { family(Guardians) }\end{array}$ & 2 & 4 \\
\hline Lack of legal framework & 5 & 10 \\
\hline Total & 50 & 100 \\
\hline
\end{tabular}

Field Data collected from Sylhet-Bangladesh, August 5-September 2, 2016.

Figure shows the reasons that why cyber bulling occurs. About $26 \%$ of the total respondent's claims relationship problem is the main causes of cyber bullying. $14 \%$ of the total respondents support Self display of girls in social media causes cyber bullying, $18 \%$ of the total respondents claims moral degradation, $10 \%$ said unemployment problem, $8 \%$ said lack of education, $4 \%$ said unawareness of girls, $6 \%$ claims intention of teenage, $4 \%$ said 
unawareness of guardian and rest of the respondent seems lack of the legal framework is liable for cyber bullying.

\subsubsection{Relationship problem}

This paper explore that cyber bullying appears most of the time for relationship problem. Break-ups, jealousy, intolerance and ganging up all are the spheres of relationship problem that leads to cyber bullying.

\subsubsection{Self-display of girls in social media}

Now a day cyber space is very open to all, there is nothing like personal in the virtual world. Exhibition of self and body via Facebook and other social media intend the young boys to so such kind of behavior like cyber bullying (Mulvey, 2004). Girls should be morally concerned about this and should be very careful to display them on the cyber world.

\subsubsection{Unawareness of girls}

Sometimes girls don't aware of what they should post on cyber space. For this reason they sometimes share their photos, videos or personal information which is used as a weapon to harass her. Sometimes girls don't care about her secrecy in course of physical relation or personal moments with their boyfriends and later this weapons are used to debase her if there creates any relationship problem with her boyfriend.

\subsubsection{Moral degradation}

In an ethically degraded culture, all offensive behavior is possible. How can a man think to harm others by revealing her personal things or doing such kind of harm which may lead him or her to exhaust his or her life? If there is any society cannot reveals itself from various kind of problems, surely to be free from this problem, morality and ethics should be established to the people.

\subsubsection{Lack of education}

Education is the only machine which turns the human being into an ethical and conscious creature which may retrain him or her from doing any evil deeds. Again, lack of education can intend him or her to hazardous situation. As most of the girls have don't know clearly about cyber bullying, its causes, impacts and don't have clear idea about the use and abuse of cyber space, they have to face such kind of offense like cyber bullying only for lacking of knowledge.

\subsubsection{Intention of teenage}

Sometimes boys bully girls just for fun or keep her in fear or sometimes from hostility to harm her or to devalue her personally or socially. The long run effects of cyber bullying is very much depended on the intention of teenage for which purposes, he bullies others.

\subsubsection{Unawareness of family (Guardians)}

To protect the children from any kind of harassment, highest level of consciousness from 
guardians (Parents or siblings or nearest relatives) is needed. Lack of proper care of guardian, sometimes causes great socio-psychological or physical harm to the children. Parents should create a friendly relationship with the children so that children can share any personal or accidental matter with them. Again if there exists so much collaboration among family members, children have little chance to spend time on cyber space to bully others or to become the victims of online bullying.

\subsubsection{Lack of legal framework}

There is no specific cyberbully act in Bangladesh rather has involved with cybercrime act. A cyberbully may also violate the Human Rights act of Bangladesh if the bully spreads hate or segregation based on nationality, ethnical minority, and religious status, gender or sexual orientation, class, social status or incapacity. Again there is culture of violating law in Bangladesh. In most cases the victim doesn't get justice even by seeking help to the law enforcement agency and sometimes the justice sides towards the strong party. Moreover, most of the victims don't know about cybercrime related legal framework.

\subsection{Socio-Psychological Impact of Cyber Bullying}

As internet and communication technology is reachable to the people from any ages involving children, teens and adults, all are under the risk of cyber bullying but adolescent girls are the worst sufferer of this hazardous social issue. It has extremely devastating impact on the socio psychological sphere of the victims. In most cases victims suffered from extreme depression, obsession, anxiety \& social and mental phobia, which intended him or her in suicidal ideations, planning and efforts to commit suicide (Allison M. Schenk \& William J. Fremouw, 2012).

\subsubsection{Emotional or psychological affect}

Table 7: Victim of mental hazard

\begin{tabular}{|l|l|l|}
\hline Opinion & Number of respondents & Percentage (\%) \\
\hline yes & 49 & 98 \\
\hline No & 0 & 0 \\
\hline No Answer & 1 & 2 \\
\hline Total & 50 & 100 \\
\hline
\end{tabular}

Field Data collected from Sylhet-Bangladesh, August 5-September 2, 2016.

This figure reveals that $98 \%$ of the total respondents support the statement that the victims of cyber bullying has to suffer from extreme psychological hazard, there is no respondent who 


\section{Macrothink}

didn't appreciate this statement and rest of the respondents didn't give their opinion about this statement.

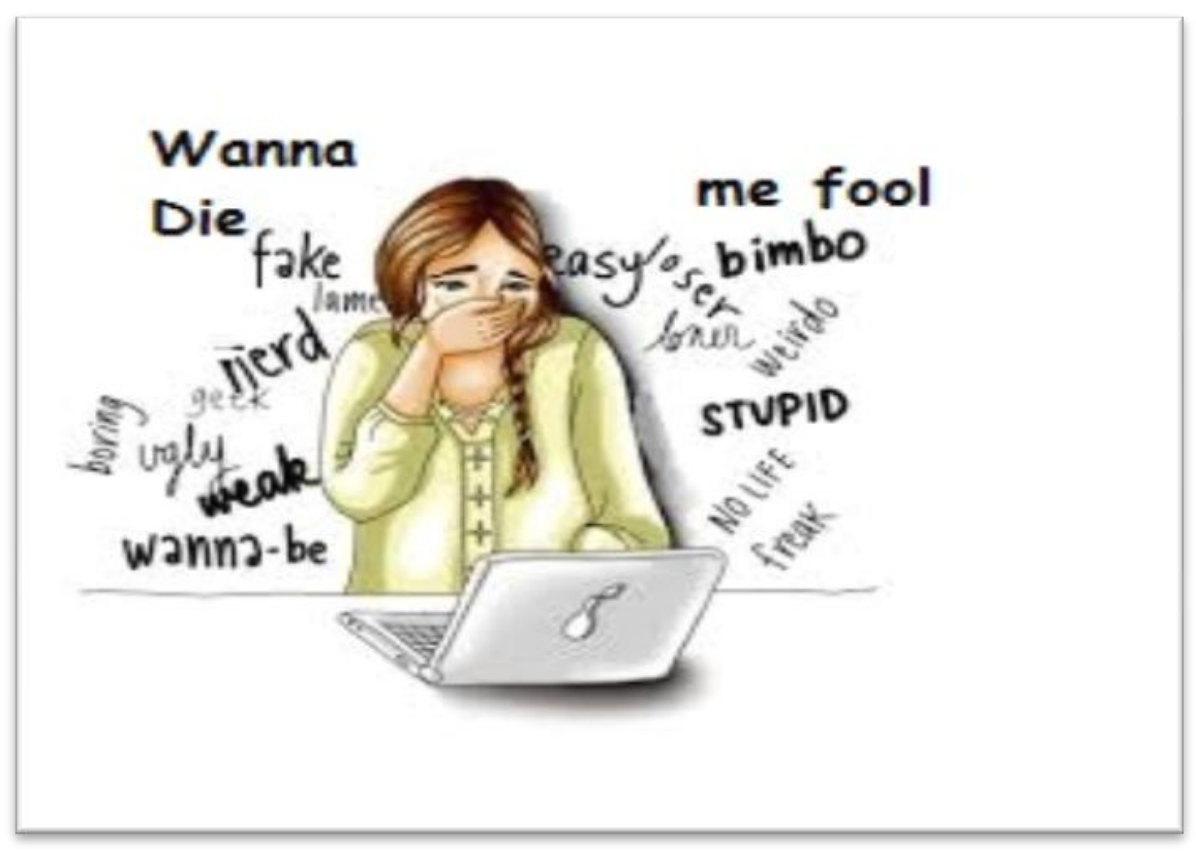

\section{Figure 7: Psychological effect of cyber bullying towards girls}

One of the most dangerous impact of cyber bullying is that the victims has to carry out a serious mental hazard. Sometimes girls carry the tremendous experience of cyber bullying alone and confined herself with her own circle avoiding family or friends for fear or being ashamed of if she will be judged or claimed for this incidents, which brings her with such an extreme psychological anxiety that may lead her to destroy herself or to commit suicide. It can also affect the person academically because their lack of confidence will prevent them from contributing and asking questions in class

\section{- Cyber bullying and suicidal behaviour}

This study focus on the possibility of suicidal behaviour due to cyber bullying.

Table 8: Is Cyber bullying increases suicidal behavior?

\begin{tabular}{|l|l|l|}
\hline Opinion & Number of respondents & Percentage (\%) \\
\hline Yes & 50 & 100 \\
\hline No & 0 & 0 \\
\hline No answer & 0 & 0 \\
\hline
\end{tabular}




\section{Total}

50

100

Field Data collected from Sylhet-Bangladesh, August 5-September 2, 2016.

From this figure, it is clear that cyber bullying increases the suicidal behavior among the teenagers. Both victim and criminal of cyber bullying think about suicide, sometimes try to commit suicide. Marr and Field (2001) denoted to suicide caused by cyber bullying as "bullycide" (Marr \& Field, 2001, p. 1).The victims affected with extreme mental depression may commit to suicide.

\section{Case Study: Rabeya, a Victim of Cyber Bullying}

For 16-year-old Rabeya, living in a small town in Sylhet. The introduction of the Internet was a blessing in many ways. With strict parents who did not allow her to go out of the house alone, she was glad to have access to another world where there was no one overseeing her interactions or telling her what to do. Before long, she developed a relationship with a man who claimed to be working in a bank in Dhaka, with whom she shared intimate details of her life. After a few months of chatting, he demanded that she send him explicit pictures of herself. When she refused, his whole demeanour towards her changed; he began to send her highly inappropriate images and videos and make derogatory comments about her appearance and character. As Rabeya tried to block and delete him from his friend list, he threatened to call her parents and tell them what a "whore" she was. The images, threats and calls became more frequent and more offensive as days passed, and with no one to ask for help, a traumatised and scared Rabeya, who blamed herself for it all, finally reached her breaking point and attempted suicide.

This is not just a story of a single girl, it represents the image of the hazardous condition of our girls who directly or indirectly, extremely or poorly affected by cyber bullying. With the advent of technology the degree of cyber bullying is increasing rapidly. Now it is a common concern of Bangladesh - is the girls are safe in cyber space? In Bangladesh there is lots of examples like Rabeya who attempts to suicide finding no way being extremely affected by cyber bullying.

\section{- Cyber bullying and somatic concerns}

Only a limited research is conducted measuring the long run impact of cyber bullying on the victims physical health. There is close connection between cyber bullying and psychosomatic complications involves with the complications of sleeping, stomach aches, deficiency of 
appetite, headaches etc. Both the bullied and criminal have to face this problematic symptoms. As cyber bullying tends to extreme psychological hazard to the victim, sometimes they may involve themselves in alcohols or drug addiction. Suffering from mental agony may limit his or her capacity to socialism and covered the victim with her own internal arena keeping far themselves from family, friends and society.

\subsubsection{Social affect}

One of the most desiring target of cyber bullies is to degrade the victims social situation and with the basis of target the bullies intent themselves to do anything harmful to degrade the victims social basis, spread defamation over her, lick her personal image, videos or any kind of information that is harmful for her social status. Cyber victims have a weak peer interactions and sometimes refrain themselves from groups or society, again the bullies have a strong popularity over the groups but may show behavioural difficulties (Gleeson, March, 2014).

a. Defamation: Defamation is when the person who is bullying causes harm to someone's reputation by spreading false information about that person. In general, defamation that appears temporarily. The person cyber bullying may be creating an unsafe environment by making the target feel that she or he cannot go to school without facing violence, teasing or exclusion. Schools and workplaces are required to provide a safe environment for their students or employees, and must take any appropriate action to do so. A school, therefore, might punish a student for online behavior that is making it hard for other students to learn in a safe environment. In Ontario, the Safe Schools Act has been changed to specifically include online behavior: students can now be suspended or expelled for cyber bullying, even if it is done outside the school. A school or workplace that does not do everything it can to provide a safe environment can be sued by the target. Even if a statement is not libelous, spreading it around might still create an unsafe environment

\section{b. Early Marriage:}

Table 9: Early marriage due to cyber bullying

\begin{tabular}{|l|l|l|}
\hline Opinion & Number of respondents & Percentage (\%) \\
\hline Yes & 40 & 80 \\
\hline No & 6 & 12 \\
\hline No answer & 2 & 4 \\
\hline Total & 50 & 100 \\
\hline
\end{tabular}

Field Data collected from Sylhet-Bangladesh, August 5-September 2, 2016. 
In some case, the electronic bullying escalate early marriage and increase drop out of the girl students. The families being socially degraded try to get relief from the bullying by early marriage, girls students are bound to drop out from school and are fancied with their own arena.

c. Family response of cyber bullying: Cyber bullying often bring hazards to a family from a girls who being bullied. Sometimes the victim girls are disbelieved and made liable for the incidents. The guardians often blame their girl for the incidents and take step against her as punishment. As the victim girls cannot find anyone beside her that can create a great effect or serious incidents like suicidal behavior.

\section{- Family support rate of victim}

This figures shows the family support rate of the victim of the cyber bullying reveals that whether the victim gets support or help from their family.

Figure 8: Family support rate of cyber bullying

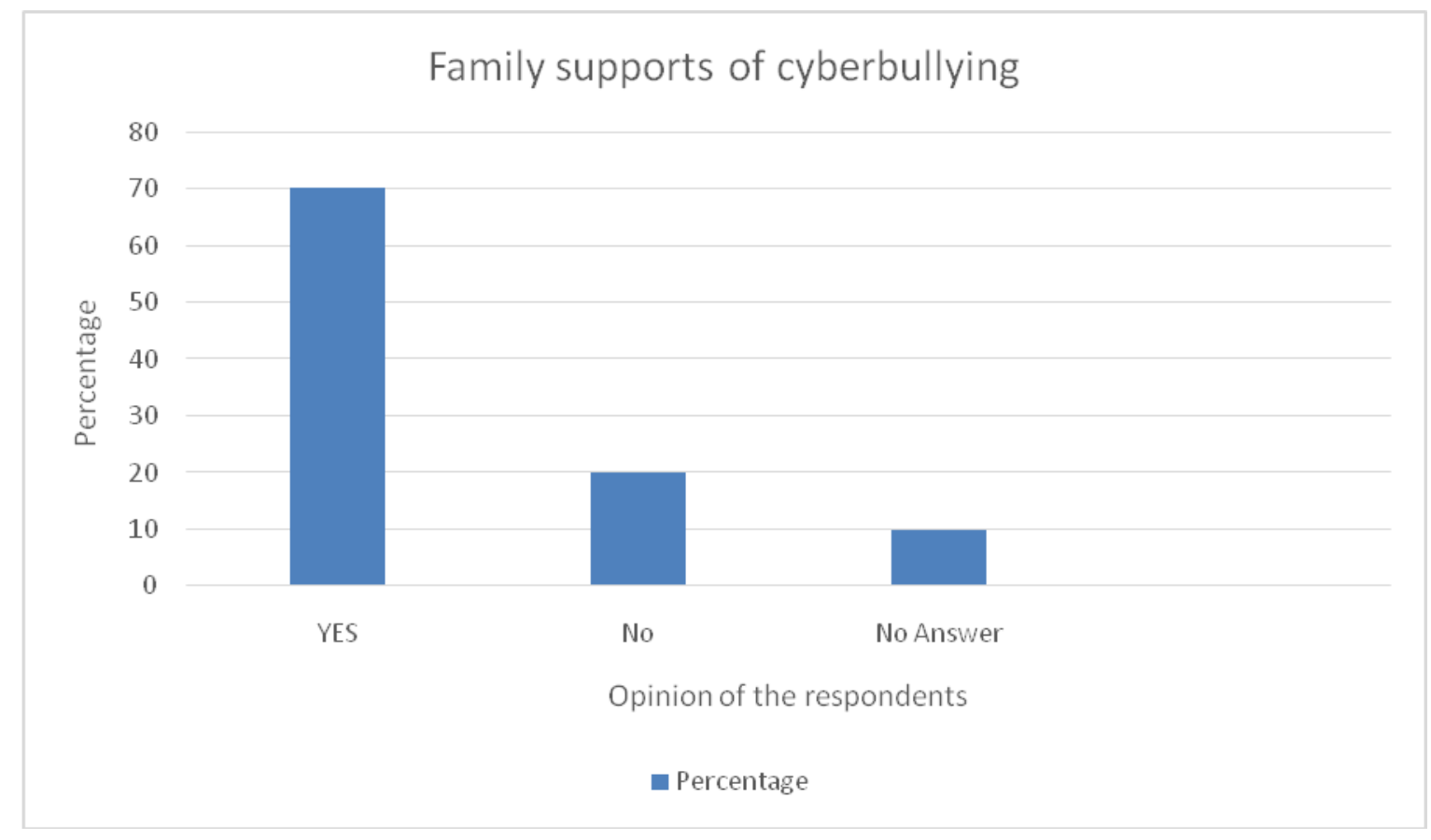

Field Data collected from Sylhet-Bangladesh, August 5-September 2, 2016.

Here, about $70 \%$ of the total respondents support on the statement that the victim's get help from their family and $20 \%$ of the total respondents says they didn't get support from the family and rest $10 \%$ didn't give answer to the statements.

\section{- Most helpful person}

This figure reveals who support mostly to the victim of cyber bullying. 
Figure 9: Supportive person in case of cyber bullying

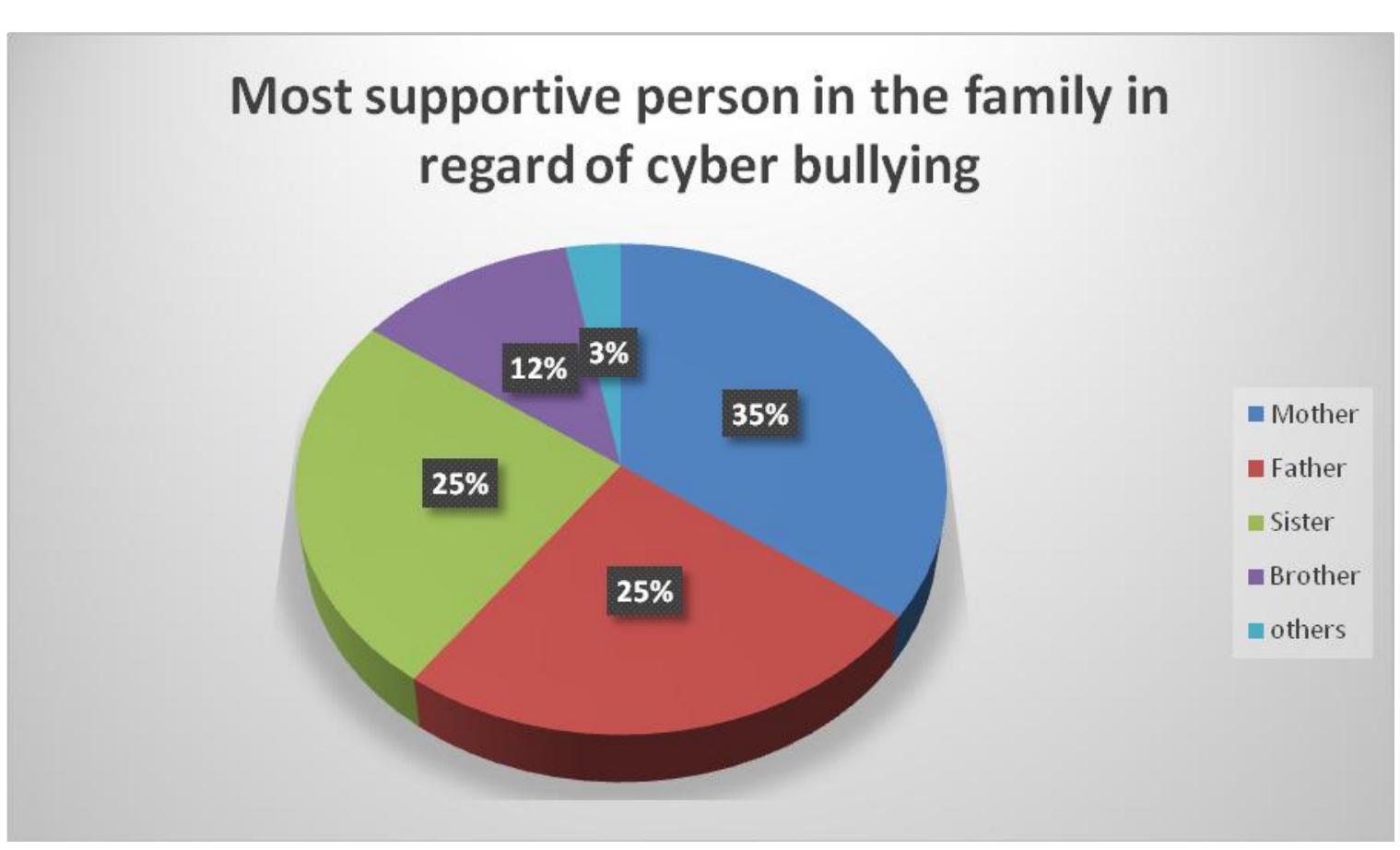

Field Data collected from Sylhet-Bangladesh, August 5-September 2, 2016.

This figure reveals that $35 \%$ of the total respondents branded mother as the most supportive, $25 \%$ branded father, $25 \%$ support sister, $12 \%$ support brother and $3 \%$ support other members of the family as the most supportive person in the family in case of cyber bullying.

- Reason behind getting no support from nearest

Why the victim didn't get any support from the family? Here, we tried to find the answer of this question from our respondents. 
Figure 10: Reasons behind the victim not supported by the family

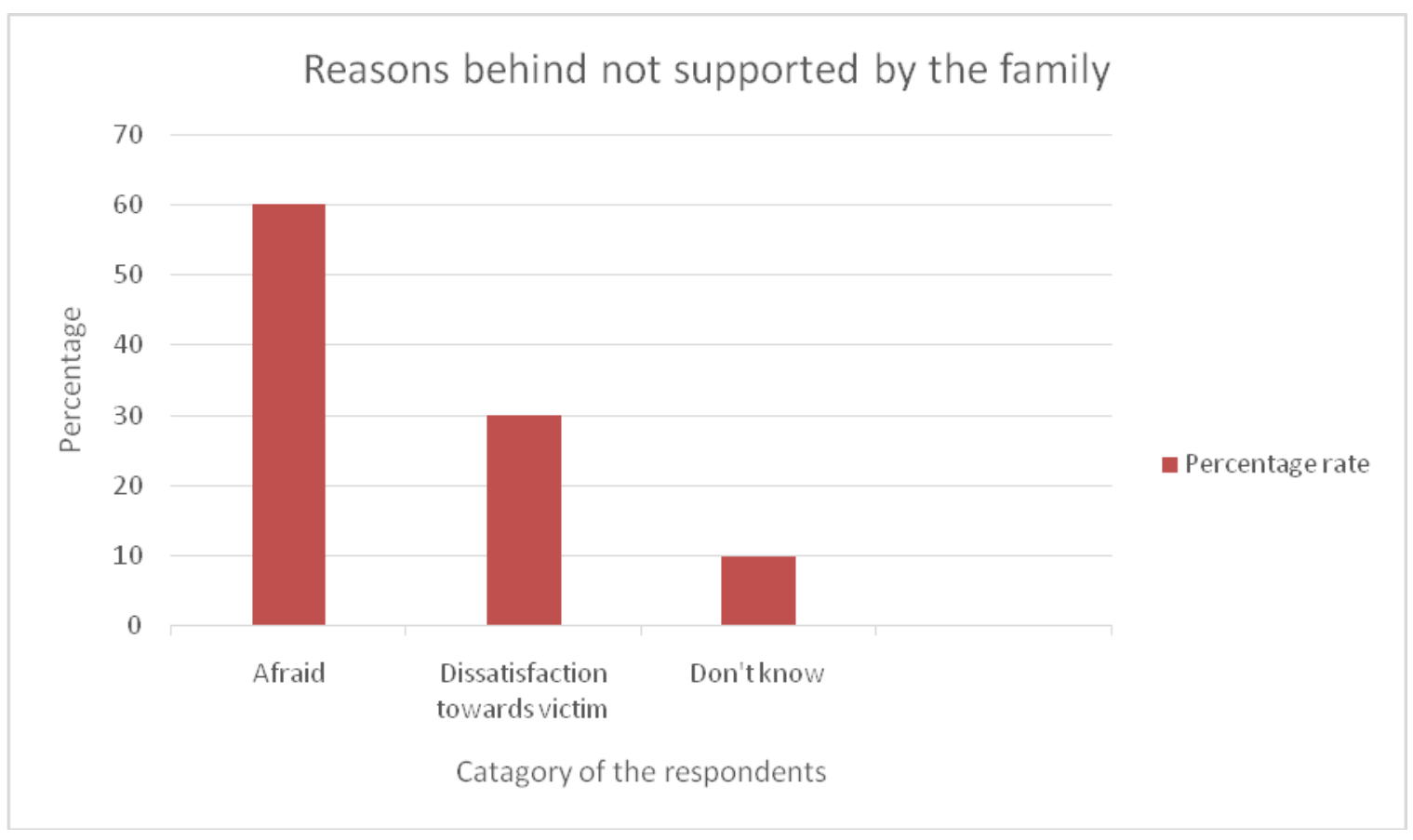

Field Data collected from Sylhet-Bangladesh, August 5-September 2, 2016.

$60 \%$ of the total respondents think the victim cannot inform to her family because of fear, so there is no chance for getting support from the family. $30 \%$ of the total respondents seems the victim doesn't get support from the family because of their family's dissatisfaction toward them and rest of the respondents said that they don't know about this.Here, $10 \%$ of the total respondents said "Yes",50\% said they don't know about the law,39\% said they don't have clear idea about cyber bullying law and rest of the respondents didn't give answer.

d. Helplessness: Cyber bullying creates a sense of helplessness among the victims. Sometimes the friends and nearest don't tend to keep aside the victim, so the victim feels helplessness and insecure.

e. Moral Decay: With the progress of technology, electronic crimes are increased because most of the people are not inclined to accept the good and reject the evil side of technology. For a morally decade person, all kind of evil is possible.

f. Criminal Behavior among Adolescents: Both the bullies and victims are in the risk of criminal behavior, sense of criminality will be inspired towards bullies and his friends for conducting a successful bully and the victims may involves him or herself in criminal behavior being affected by cyber bullying.

g. Increase unemployment problem: youths are involved them in doing online harassment and spending more time in virtual world, they don't give more time on study, so cyber bullying increases the number of unemployed youths in our country. 
h. Premature Death: Cyber bullying and suicidal behavior are closely connected. Both youths are the victim of the cyber bullying, it increases the unexpected premature death of the youths.

i. Obstacles of proper growth of youths: As both adolescents are both the victims and bullies of cyber bullying, it resists the proper growth of adolescents. Because cyber bullying seriously affected the victim seriously, besides the bullies who intent to harm of others is a sign of deviant from the society.

j. Decadence of Social values: That kind of activities which tends to an individual into a serious socio psychological hazards is clearly a sign of decadence of social values. When ethics and morality is overlooked, when norms and values of the society are dis-graded, this kind of unexpected behavior becomes copious in the society.

\section{Conclusion}

Now, we are a developing country and trying our best to be a developed one. In order to digitalize Bangladesh there is no substitute to secured technological expansion among which tenable internet using should prevail in priority. Cyber bullying is now a social problem. As women or girls are the most agonized tools in any kind of harassment, they have to pay great sufferings for sharing or posting their photos, videos or information or sometimes just for prevailing in cyber world. In this paper we explored multifaceted causes and long term impact of cyber bullying on our personal, family or social life. Computer and technology is the fabricator of cyber bullying and we believe that by computer and technology, this problem can be mitigated. A wide range of tactics and interventions are accessible but we need more assessment for the application of the strategies. Again, an effective legal framework is needed and the culture of maintaining law should be established. Individuals actions, family support, social supports, legal procedures, everything have a great part to act to mitigate the problem.

\section{References}

Hinduja, S. \&Patchin, J. W. (2009). Bullying beyond the schoolyard: Preventing and Responding to cyber bullying. Sage Publications: Corwin Press.

Belsey, B. (2004). What is cyber bullying? Retrieved August 15, 2016, from:www.bullying.org/external/documents/ACF6F8.pdf

Aminuzzaman, S.M. (2011). Essentials of Social Research.Osder Publications, Dhaka: Bangladesh.pp:51-52.

Kamal, Mohammad Mostufa.Chowdhury, Iqbal Ahmed.Haque, Nadia. Chowdhury, Mydul Islam \&Islam,MohammadNazrul (2012).Nature of Cyber Crime and Its Impacts on Young People: A Case from Bangladesh.

Kawolski,Robin M., Limber,Susan P.,\&Agatston,Patricia W.(2012).Cyber bullying: Bullying in the Digital Age. Blackwell Publishing Ltd, page No: 1. 
The ProthomAlo (2016), Retrieved on 09.02.16, from http://en.prothom-alo.com/science-technology/news/94649/Almost-50pc-Bangladeshi-student s-face-cyber

Boyd, D. M, Ellison, N.B. (2007). "Social Network Sites: Definition, History, and Scholarship". Journal of computer-mediated communication, 13 (1), 210-230.

Gleeson, Helen (March, 2014).The Prevalence and Impact of Bullying Linked to Social Media on the Mental Health and Suicidal Behavior among the Young People.

Reilly, Brendan (2011).Cyber-Bullying: Freedom of Expression vs. Freedom from Harassment.

Aune, Nicole M. (2009, December).Cyber bullying. The Graduate School, University of Wisconsin-Stout.

Willard, N.B. (2007, March). Cyber bullying legislation and school policies: Where are The boundaries of the "schoolhouse gate" in the new virtual world? Center for Safe and Responsible use of the Internet. Retrieved September 3, 2016, from:http://csiru.org

Marr, N., \& Field, T. (2001). Bullycide: Death at playtime. Didcot, Oxfordshire: Success Unlimited.

Schenk, Allison M., Fremouw,William J. (2012).Prevalence, Psychological Impact, and Coping of Cyberbully Victims among College Students Journal of School Violence. Volume 11, Issue 1.

Campbell, Marilyn A (2005).Cyber bullying: An old problem in a new guise? Australian Journal of Guidance and Counselling, 15(1), 68-76.

Beale, A.V., \& Hall, K.R. (2007, September/October). Cyber bullying: What school Administrators (and parents) can do? The Clearing House, 81(1), 8-12.

\section{Copyright Disclaimer}

Copyright for this article is retained by the author(s), with first publication rights granted to the journal.

This is an open-access article distributed under the terms and conditions of the Creative Commons Attribution license (http://creativecommons.org/licenses/by/3.0/). 